\title{
Use of corporate sponsorship as a tobacco marketing tool: a review of tobacco industry sponsorship in the USA, 1995-99
}

\author{
N Jennifer Rosenberg, Michael Siegel
}

\begin{abstract}
Objective-To describe the nature and extent of tobacco company sponsorship in the USA during the period 1995-99 and analyse this sponsorship in a marketing context.
\end{abstract}

Design-A cross-sectional study of tobacco company sponsorships identified through a customised research report from IEG Inc, and from internet web site searches.

Methods-First, a customised report was received from IEG Inc, which identified sponsorship activities for Philip Morris, RJ Reynolds, Brown \& Williamson, Lorillard, and US Tobacco for the years 1997 and 1998. Second, the internet was systematically searched for tobacco industry sponsorships during the period 1995-99 by the same parent companies and their respective brands.

Results-During the period 1995-99, tobacco companies sponsored at least 2733 events, programmes, and organisations in the USA. Sponsorships involved all 50 states and the District of Columbia, and the minimum total funding amount of these sponsorships was $\$ 365.4$ million. Tobacco corporate sponsorships involved numerous small, community based organisations, both through direct funding and through grants to larger umbrella organisations, and many of these organisations were part of the public health infrastructure.

Conclusions-Tobacco corporate sponsorship serves as an important marketing tool for tobacco companies, serving both a sales promotion and public relations function. Public health practitioners need to develop better surveillance systems for monitoring tobacco sponsorship, to seek out alternative funding sources for tobacco company sponsored events and organisations, and to consider promoting a ban on tobacco sponsorship, possibly linking such regulation to the creation of alternative funding sources.

(Tobacco Control 2001;10:239-246)

Keywords: marketing; sponsorship; tobacco industry

Corporate sponsorship of events and organisations is a well recognised marketing tool. ${ }^{1-4}$ In the marketing literature, sponsorship is noted to enhance a corporation's image, to associate the name of a sponsoring company with causes that are important to a particular target group, to offer effective product exposure, to target specific populations including groups that are difficult to reach through more traditional forms of advertising, and to provide publicity for a company through highly visible activities. ${ }^{1-4}$ Corporate sponsorship of, and donations to, social causes has been termed "cause related marketing" and its purposes, according to Kotler, are to "enhance corporate image, thwart negative publicity, pacify consumer groups, launch a new product or brand, broaden their customer base, and generate incremental sales" (page 29). ${ }^{3}$ According to IEG Inc, the leading national source for sponsorship research, corporate sponsorship in North America has become so popular that it grew from $\$ 850$ million in 1985 to $\$ 7.6$ billion in $1999 .^{56}$

Tobacco companies are increasingly using corporate sponsorship as an important component of their marketing mix. From 1995 to 1999, cigarette company spending on public entertainment increased from $\$ 110.7$ million to $\$ 267.4$ million, and spending on sports sponsorship increased from $\$ 83$ million to $\$ 113.6$ million. $^{78}$

In contrast to the large body of published research on cigarette advertising, research on cigarette company sponsorship is limited. Although sponsorship appears to be an increasingly important tobacco marketing tool, we are not aware of any systematic, comprehensive review of tobacco industry sponsorships. The existing research consists largely of anecdotal reports of specific tobacco sponsorships, focusing mainly on motor sports sponsorships $^{9-15}$ and sponsorships targeted towards the African American community, ${ }^{16-20}$ towards the Hispanic community, ${ }^{18-21}$ and towards women. ${ }^{18-20} 22 \mathrm{We}$ are aware of only one article that attempted to summarise overall patterns of tobacco sponsorship, and this report consisted mainly of anecdotal reports of sponsorships. $^{23}$

The purpose of this paper was to collect, organise, and summarise information on the nature and extent of tobacco company sponsorship of events and organisations in the USA during a five year period (1995-99). Using two data sources-a customised research report from IEG Inc, and internet web site searches - we attempted to identify all tobacco company sponsorships in the USA during the period 1995-99. In this paper, we 
summarise our findings and discuss the implications for tobacco control practice.

\section{Methods}

DESIGN OVERVIEW

We conducted a two part search for tobacco industry sponsored events, activities, and organisations in the USA during the period 1995-99. First, we received a customised report from IEG Inc, which researched, identified, and compiled sponsorship activities for Philip Morris, RJ Reynolds, Brown \& Williamson, Lorillard, and US Tobacco for the years 1997 and 1998. Second, we systematically searched the internet for tobacco industry sponsorships during the period $1995-99$ by the same parent companies and their respective brands. The period 1995-99 was chosen because it is easiest and of most interest to collect sponsorship information for the most recent time period, and because we felt a five year time frame would provide the most accurate picture of tobacco industry sponsorship. A five year study period, for example, would correct for any short-term changes in sponsorship associated with the discussion of proposals to regulate tobacco marketing.

\section{DATA SOURCES}

IEG sponsorship report

IEG Inc, located in Chicago, is the leading national source for information and customised research on sponsorship and it is the only company that tracks and analyses sponsorship of sporting and other events and causes. It produces more than 13 publications on event sponsorship, runs an annual event marketing conference, and conducts detailed research on sponsored events that is not available elsewhere. Much of IEG's information on sponsorships comes from its annual survey of more than 2000 sponsorship opportunities.

We paid IEG Inc to conduct customised research and to provide a written report of their findings of 1997-98 sponsorship activities of the five major tobacco companies. ${ }^{24}$ In addition to information obtained from IEG's sponsorship surveys and other existing sources, the company conducted customised research for us, making additional telephone calls to potential properties that may have been sponsored by tobacco companies. The final report included the sponsoring company and/or brand, property, property type, type of sponsorship, sponsorship status, location, affiliation, attraction, series, or programme, estimated annual sponsorship fee, current term, and IEG product and sponsorship category.

\section{Internet search}

We conducted a systematic search for web pages that made reference to tobacco sponsorship of events, activities, or organisations in the USA during the period 1995-99. The search engines used were Excite, Hotbot, Infoseek, Lycos, Netscape, and Yahoo. The key words used were the parent companies (Philip Morris, RJ Reynolds, Brown \& Williamson, Lorillard, and US Tobacco) and major corresponding brands (Marlboro, Benson \& Hedges, Merit, Basic, Virginia Slims, Parliament, Capri, Carlton, Kool, Misty, Newport, Camel, Doral, Salem, and Winston) for the five major tobacco companies. To ensure that we correctly identified relevant web pages, we additionally conducted boolean searches using each of the following additional key words: sponsor, sponsorship, fund, funding, contribute, and contribution. A total of 1500 web sites were retrieved during our internet search.

INCLUSION AND EXCLUSION CRITERIA

All tobacco industry sponsorships in the USA during the period 1995-99 were included in the study. We excluded tobacco company financial contributions to politicians or political candidates; however, provision of travel for, or hosting of, fact finding missions and conferences was included. Sponsorships solely under the name of a non-tobacco subsidiary of a parent company (for example, Kraft, Nabisco, and Miller Brewing Company) were not included. For example, we included in the study sponsorships listed under RJR Nabisco or RJ Reynolds Tobacco Company, but not under Nabisco.

\section{DATA COMPILATION}

The internet data were combined with the IEG report and sponsorships were then categorised by type of sponsorship and demographic group involved. If a sponsorship appeared to fall in two categories, we chose the category which we felt best described the sponsorship. In one case, a sponsorship appeared to fall equally between two categories and was included in both. We also noted the amount of the sponsorship, if available, and the location of the sponsored event or organisation. A complete listing of the identified sponsorships was compiled into a written report, which is available on the internet. ${ }^{25}$ In no cases were there any discrepancies between data reported by IEG and data retrieved from the internet.

\section{Results}

DESCRIPTIVE EPIDEMIOLOGY OF TOBACCO

INDUSTRY SPONSORSHIP

During the period 1995-99, we identified 300 tobacco industry sponsorships in the USA, involving a total of at least 2733 events, activities, and organisations (table 1).

Analysis of sponsorships by category

The performing arts received the largest number of sponsorships (56), followed by minorities (41) (table 1). However, the categories in which the most organisations or events received funding were rodeo (1527), motor sports (348), domestic violence (182), and hunger (180).

\section{Analysis of sponsorships by state}

Sponsorships under two categories-domestic violence and hunger-involved all 51 states (table 1). Sponsorships under four additional categories-AIDS, minorities, motor sports, and rodeo-involved more than half of the 
states. Every state in the USA and the District of Columbia had at least two identified tobacco company sponsorships during the study period. The top 10 states for overall number of sponsorships were New York (71), California (39), District of Columbia (33), Virginia (34), Illinois (34), North Carolina (31), Texas (31), Kentucky (24), Massachusetts (22), and Georgia (20).

Analysis of sponsorships by company

Of the 300 identified sponsorships, Philip Morris was involved in 244, RJ Reynolds in 36, Brown \& Williamson in 21, and US Tobacco in 21 . We identified no programmes, organisations, or events sponsored by Lorillard.

Analysis of sponsorships by amount of funding Although funding information was available for only a limited number of the sponsorships, we compiled sponsorship funding amounts where they were available in order to generate a bare minimum estimate for the sponsorship funding involved. We estimate that tobacco companies spent no less than $\$ 365$ million on sponsorship during the study period (table 1). The category with the highest minimum total amount of sponsorship funding was motor sports at $\$ 208$ million, followed by hunger at $\$ 104$ million.

We identified 25 sponsorships (13 in the motor sports category) with an estimated sponsorship amount of one million dollars or more (table 2). These 25 sponsorships alone provided funding to 2267 individual events, programmes, or organisations throughout the country.

Analysis of sponsorships by nature of organisation Sponsorship of small, community organisations - Although some tobacco sponsorships supported large national organisations, we found many sponsorships in which the money was directed at small, local organisations serving individual communities. Many of the sponsorships provided large grants to be disbursed to numerous community organisations (table 2). In addition, the tobacco industry funded many small, local organisations directly.

Sponsorship involving the public health infrastructure-A total of 33 sponsorships, funding 446 causes, events or organisations in all 50 states and the District of Columbia, were part of the public health infrastructure. There were 65 AIDS related events or organisations, 182 domestic violence organisations, 29 environmental protection causes, and 180 anti-hunger organisations benefiting from tobacco industry sponsorship during the study period.

\section{ANALYSIS OF SPONSORSHIPS IN A MARKETING} CONTEXT

When viewed in the context of sponsorship being a marketing tool, several general findings emerged from our review of tobacco industry sponsorships.

\section{Promotion of brand awareness and positive brand} associations

While most of the sponsorships were in the name of the parent company, several were brand name sponsorships that allowed companies to promote awareness of specific cigarette brands and to foster the association of the brand with a particular image. The titling of specific sports and music events with large event and/or television audiences helped to facilitate this. For example, through its sponsorship of pool and billiards, RJ Reynolds was able to promote the Camel brand by attaching it as a title to three different tournaments: the Camel Pro Billiards Series, Camel 8-Ball Classic, and Camel 8-Ball National Team Championships (table 2). Other sponsorships that allowed companies to promote awareness of specific brands and associations of those brands with music or sport included the Senior PGA Tour Vantage Championship, NASCAR Winston Cup Series, the NHRA Winston Drag Racing Series, the Kool Green Team, Team Winston, the Copenhagen Team, the Skoal Bandit

Table 1 Tobacco industry sponsored events, programmes and organisations-USA, 1995-99, by category

\begin{tabular}{|c|c|c|c|c|}
\hline Category & $\begin{array}{l}\text { Number of } \\
\text { sponsorships }\end{array}$ & $\begin{array}{l}\text { Number of events, } \\
\text { programmes or } \\
\text { organisations } \\
\text { sponsored }\end{array}$ & $\begin{array}{l}\text { Number of states } \\
\text { in which events or } \\
\text { organisations were } \\
\text { located }\end{array}$ & $\begin{array}{l}\text { Minimum total amount of } \\
\text { sponsorship funding for sponsored } \\
\text { events, programmes, and } \\
\text { organisations in category }\end{array}$ \\
\hline AIDS & 5 & 65 & 26 & $\$ 1026000$ \\
\hline Charities/causes & 20 & 22 & 9 & $\$ 5856000$ \\
\hline Domestic violence & 2 & 182 & 51 & $\$ 2000000$ \\
\hline Education & 37 & 53 & 19 & $\$ 6203400$ \\
\hline Environment & 15 & 29 & 15 & $\$ 106500$ \\
\hline Festivals & 10 & 12 & 7 & $\$ 245000$ \\
\hline Hunger & 11 & 180 & 51 & $\$ 104174000$ \\
\hline Minorities & 41 & 78 & 31 & $\$ 2017000$ \\
\hline Motor sports & 33 & 348 & 27 & $\$ 208300000$ \\
\hline Performing arts & 56 & 74 & 19 & $\$ 2290000$ \\
\hline Politics/government & 12 & 43 & 6 & $\$ 88640$ \\
\hline Rodeo & 11 & 1527 & 36 & $\$ 3250000$ \\
\hline Sports† & 3 & 55 & 10 & $\$ 15250000$ \\
\hline Visual arts & 24 & 31 & 14 & $\$ 1796000$ \\
\hline Women & 10 & 33 & 11 & $\$ 4056000$ \\
\hline Youth & 11 & 11 & 10 & $\$ 8820000$ \\
\hline Total: & 300 & 2733 & 51 & $\$ 365356540$ \\
\hline
\end{tabular}

*Sponsorship amount could only be ascertained for a limited number of the identified sponsorships. Therefore, figures in this table represent a bare minimum for the amount of sponsorship funding in each category.

†Sponsorships of rodeo and motor sports events are included as separate entries.

$\ddagger$ Total is less than the sum of the column figures because one sponsorship was included in two categories. 


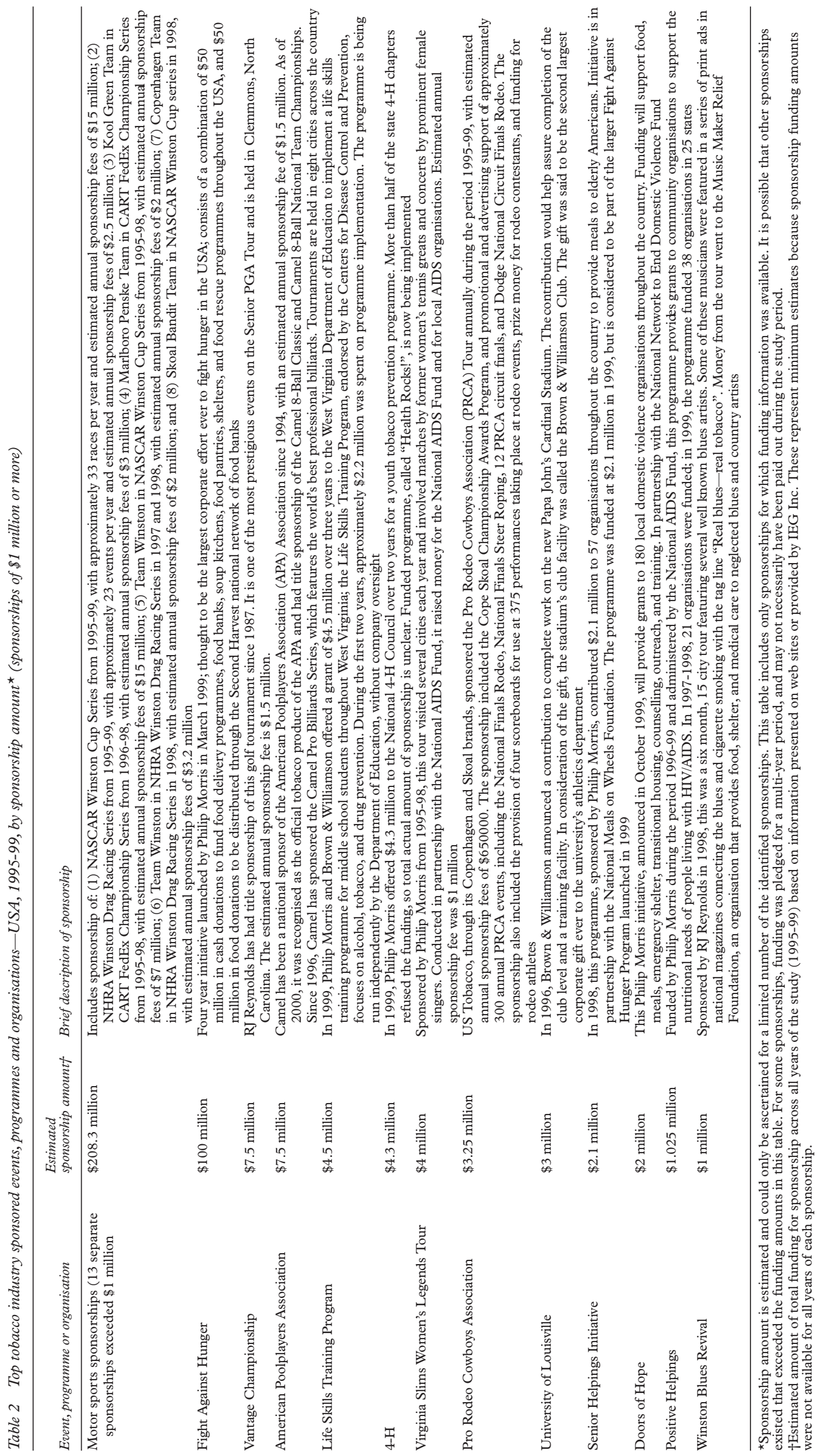


Team, the Virginia Slims Women's Legends Tennis Tour, and the Winston Blues Revival (table 2).

Sponsorships not only promote brand awareness among people in attendance at sponsored events. They also may allow cigarette companies to achieve the equivalent of paid television advertising, despite a federal ban on tobacco advertising on television. Based on an analysis of the amount of clear, in-focus exposure time achieved by tobacco company names and logos during televised motor sports events, the companies achieved the equivalent of $\$ 410.5$ million in television advertising value from motor sports sponsorships during the years 1997-99 alone. ${ }^{26}$ This may explain why motor sports sponsorship was by far the leading sponsorship expenditure for tobacco companies.

Direct promotion of company awareness and positive company associations

In consideration of the contributions made by tobacco companies, many of the sponsored organisations used the parent company name in the titling of a programme, event, or facility. This allowed the sponsoring company to promote awareness of the company as well as to associate the company name directly with a favourable activity or image. For example, in consideration of its $\$ 3$ million dollar gift to help construct the University of Louisville's new football stadium, the stadium's club facility was named the Brown \& Williamson Club (table 2). This allowed for a long term association of the company name with the excitement, competition, and action of Louisville football. Other sponsorships we identified in which the sponsoring company was given title sponsorship of a programme, event or facility included the Philip Morris Center for Organizational Renewal at Catawba College, the Philip Morris Agricultural Leadership Development Program, the RJ Reynolds Forest Aviary at the North Carolina Zoological Park, the Philip Morris Festival of Stars and Brown \& Williamson Derby Fest at the Kentucky Derby Festival, the Philip Morris Humanities Forum at the Huntington Theatre Company in Boston, and the Philip Morris Mixed Doubles Championship bowling tournament.

\section{Co-marketing opportunities}

Several of the sponsorships allowed companies the opportunity to combine sponsorship with more traditional advertising to promote a particular product image. For example, RJ Reynolds was able to integrate a traditional print advertising campaign into its 1998 sponsorship of the Winston Blues Revival to promote Winston's image as a "No Bull" cigarette brand. The company ran a series of print advertisements featuring prominent blues musicians and using the slogan "Real Blues-Real Tobacco" in Rolling Stone and other magazines in conjunction with the Revival. ${ }^{27}$ Philip Morris integrated print advertising into the Virginia Slims Women's Legends Tennis Tour sponsorship to associate the Virginia Slims brand with legendary women's tennis stars. ${ }^{27}$ Similarly, RJ Reynolds ran a series of print advertisements in Sports Illustrated in 1997 to promote the Camel Pro Billiards Series and associate the Camel product with images associated with pool playing. ${ }^{27}$

Achieving recognition as a good corporate citizen Through the sponsorships we identified, tobacco companies have achieved a great deal of recognition as good corporate citizens. Often, this recognition was achieved publicly (for example, in major media) and it therefore had the potential to create good will for the companies among the public. For example, after Brown \& Williamson announced its $\$ 3$ million contribution to help build a new football stadium at the University of Louisville, the university president stated in a press release: "We welcome Brown \& Williamson to the great family of corporate citizens who have stepped forward to make the entire stadium project, including what will be a magnificent Brown \& Williamson Club, a reality." 28 In 1999, the Blues Foundation awarded its Blues Sponsor of the Year Award to RJ Reynolds for its sponsorship of the Winston Blues Revival. ${ }^{29}$ In 1999, Hispanic Magazine listed Philip Morris among its "Hispanic Corporate 100" (the 100 companies providing the most opportunities for Hispanics) and reported that Philip Morris received the 1998 Corporation of the Year award from the US Hispanic Chamber of Commerce. $^{30}$

\section{Discussion}

To the best of our knowledge, this is the first study to examine systematically tobacco industry sponsorship of events, activities, and causes for a given time period. We found that during the period 1995-99, tobacco companies sponsored at least 2733 events, programmes, and organisations in the USA. Sponsorships involved all 50 states and the District of Columbia and the minimum total funding amount of these sponsorships was $\$ 365.4$ million. We found that tobacco corporate sponsorships involved numerous small, community based organisations, both through direct funding and through grants to larger umbrella organisations, and that many of these organisations were part of the public health infrastructure.

There are two important limitations of this research. First, although we attempted to identify all tobacco company sponsorships during the period $1995-99$, we were unlikely to have succeeded in doing so. Our data were limited to sponsorships identified through IEG Inc, or through an internet search. Because many small organisations do not have web sites, we most likely missed a considerable number of sponsorships of small organisations that would not have been identifiable on the internet. Moreover, we had information on funding levels for only a limited number of the sponsorships. Our estimate of total spending on tobacco corporate sponsorships is clearly a large underestimate, and is only provided to indicate the minimum level of funding 
identified and to provide some sense of the relative funding levels by category of sponsorship.

It is difficult to assess the extent to which this report underestimates the true amount of tobacco company sponsorship in the USA because there is no adequate surveillance system for tobacco company sponsorships. However, the Federal Trade Commission (FTC) does report sports sponsorship expenditures, allowing us to check a subset of our results. For the years 1995-99, total reported cigarette and smokeless tobacco expenditures in this category were $\$ 650.1 \mathrm{mil}$ lion. ${ }^{783132}$ Our estimated total for sports sponsorships during the study period (including motor sports and rodeo) was $\$ 226.8$ million, or $35 \%$ of total FTC measured spending for sports sponsorships. This analysis suggests that we are underestimating tobacco sponsorship expenditures by a factor of about three to one. It should be noted, however, that FTC estimates of sports sponsorship expenditures include spending on traditional advertising associated with these events, which is not included in this research. Thus, our underestimate of sports sponsorship spending is actually off by somewhat less than a factor of three to one.

Undoubtedly, one reason for our underestimate is that we included sponsorship funding in the totals only if we could confirm these fees separately for each year. Since IEG reported data mainly for 1997-98, we are often missing sponsorship fees for 1995, 1996, and 1999, even though we know the tobacco companies sponsored a given event in 1997 and 1998. Although we conducted internet searches for events in all years, web sites do become outdated, and the internet most likely contains more information on more recent sponsorships. For both of these reasons, our sponsorship estimates for 1997-99 are probably more accurate than our estimates for the years 1995 and 1996. A second component of our underestimate is the fact that many web sites did not list sponsorship fees, even though they listed tobacco companies as being corporate sponsors. The remainder of our underestimate is likely due to actually missing sponsorships because they were not captured by either IEG or by the internet search process.

A second important limitation is that because we relied upon internet searches for much of our information, we are dependent upon the accuracy of the information presented on these web sites. As web sites may contain inaccurate or outdated information, some of the data in this study could be inaccurate or out of date. The study is intended to provide a general overview of the nature and extent of tobacco company sponsorships, and it should not be relied upon for information about specific sponsorships.

Despite these limitations, we conclude from our analysis that corporate sponsorship is an important part of the marketing mix for tobacco companies, and that if public health practitioners wish to counteract the impact of tobacco marketing on smoking behaviour, ${ }^{15}$ they must find a way to eliminate tobacco sponsorship. We found that the identified sponsorships enabled tobacco companies to promote brand and company awareness, to develop brand and company associations with attractive images, to create co-marketing opportunities by allowing them to combine advertising with sponsorship in promotion of a product image, and to enhance their public image by achieving recognition as good corporate citizens. Each of these functions is well recognised in the marketing literature as a major objective of corporate sponsorship. ${ }^{1-46}$

These marketing functions have two major outcomes. First, they promote tobacco sales, and therefore, the bottom line, for the sponsoring companies. Increased awareness of cigarette brands creates brand familiarity, a factor known to influence consumer buying behaviour. ${ }^{3}$ Associating a brand with attractive images influences consumers' beliefs about the brand, and therefore the brand image, another factor recognised as being a determinant of purchasing behaviour. ${ }^{3}$ Combining advertising with sponsorship allows both to work together to promote a brand image. The second outcome of the marketing functions achieved through tobacco sponsorship is enhanced corporate image, which in turn affects tobacco policy by influencing social attitudes and values regarding tobacco. Through its corporate sponsorship, a tobacco company may be able to create good will among the public, even given the recognition that tobacco is a harmful product. In other words, it may help put a "human" face on the corporation and point out its contributions to the community, taking the focus away from damage caused by its products.

As Tuckson has noted, sponsorship may provide tobacco companies with "innocence by association." ${ }^{19}$ This softening of public opinion towards the tobacco industry may make it more difficult to enact strong tobacco control policy measures and may make it less likely that juries will hold tobacco companies responsible for the harms caused by their products. For example, companies used their funding of youth anti-smoking programmes in an attempt to convince the jury in the Engle class action lawsuit that they had changed their behaviour and were committed to doing everything they could to prevent smoking among youths. ${ }^{33}$ Tobacco industry documents, however, suggest that the primary purpose of company sponsorship of youth smoking prevention programmes is to "offset further erosion of the industry's image in this area, reverse political trends and gain recognition of our efforts from public service organisations and public officials" (pages 1-2). ${ }^{34}$

Tobacco sponsorship may affect policy not only by serving a public relations function and enhancing the companies' public image, but also by creating a community dependency on tobacco company funding. Because many small organisations are funded by tobacco companies, they may be afraid to support tobacco control policies in fear that their funding may be cut off. For example, "in 1994, 
when New York City moved to ban smoking from restaurants, Philip Morris asked arts organisations to let the city council know that if the company pulled its funding, it would be a dark day for the arts" (page 3). ${ }^{35}$ Not only is there a threat for loss of funding for many small organisations, but many of the sponsorships occur in areas where there are few existing sources of alternative funding (for example, domestic violence).

Tobacco sponsorship may also weaken opposition to tobacco control policies by supporting organisations that are an integral part of the public health infrastructure, and that might otherwise be expected to advocate strongly for such policies. For example, in a Boston Globe op-ed piece, Derrick Jackson explained how tobacco sponsorship of environmental organisations may divert these organisations' attention away from environmental problems caused by tobacco: "Philip Morris's gifts buy a critical disconnect. People who preach about ecosystems, food chains, and Planet Ocean suddenly become blind to a toxic dumping that kills more people a year than the combined genocides of Rwanda, Bosnia, and Pol Pot. They run from evidence that tobacco curing and cigarette papers contribute to deforestation and that cigarette butts are the most common garbage on the nation's beaches." ${ }^{36}$

We have several recommendations for how tobacco control practitioners can begin to address the problems posed by tobacco corporate sponsorship. First, there is a need for surveillance of tobacco company sponsorship, since we have demonstrated that it represents an important tobacco marketing technique. On a national level, the FTC could monitor expenditures for all cigarette company sponsorships. Currently, the FTC only monitors sports sponsorships and a vague category of public entertainment. An ongoing surveillance system would not only track sponsorships of the kind we have documented in this paper, but would alert public health practitioners to new and emerging trends in tobacco sponsorship.

Secondly, there need to be alternative funding sources to lessen the dependency of organisations and events on tobacco company sponsorship. One potential source of such alternative funding is cigarette excise taxes or tobacco settlement funds.

Thirdly, a legislative or regulatory ban on tobacco company sponsorship (both brand name and corporate name sponsorship) should be considered. The multi-state tobacco settlement contains some limits on brand name sponsorship, but does not regulate sponsorships in the corporate name. ${ }^{37}$ Australian states such as Victoria, Western Australia, and South Australia have in fact implemented a comprehensive ban on tobacco sponsorship, and at the same time, increased the tobacco tax to provide alternative funding to organisations previously supported by tobacco companies. ${ }^{38-40}$

This research provides the first systematic overview of the nature and extent of tobacco industry sponsorship in the USA. We have

\section{What this paper adds}

In contrast to the large body of published research on cigarette advertising, research on cigarette company sponsorship is limited. The existing research consists largely of anecdotal reports of specific tobacco sponsorships. There has been no systematic, comprehensive review of tobacco industry sponsorships.

This study of tobacco company sponsorship in the USA during the period 1995-99 revealed that tobacco companies sponsored at least 2733 events, programmes, and organisations during this period, and that the minimum total funding amount of these sponsorships was $\$ 365.4$ million. These sponsorships served an important marketing role for tobacco companies by promoting brand and company awareness, promoting positive brand and company associations, and achieving for the companies recognition as good corporate citizens. To counteract the use of sponsorship as a tobacco promotional tool, public health practitioners should consider promoting legislation to eliminate this sponsorship, perhaps linking such regulation to the creation of alternative funding sources.

demonstrated that tobacco corporate sponsorship serves as an important marketing tool for tobacco companies, serving both a sales promotion and public relations function. To address this issue, public health practitioners need to develop better surveillance systems for monitoring tobacco sponsorship, to seek out alternative funding sources for tobacco company sponsored events and organisations, and to consider regulation of tobacco sponsorship, possibly linking such regulation to the creation of alternative funding sources.

This work was supported by research project grant \#RPG-98-264-01-PBP from the American Cancer Society. A complete report and full listing of tobacco corporate sponsorships identified in this research project is available on the internet at $<$ http://dcc2.bumc.bu.edu/tobacco $>$

1 Gardner MP, Shuman PJ. Sponsorship: an important component of the promotions mix. Fournal of Advertising 1987; 16:11-7.

2 Mescon TS, Tilson DJ. Corporate philanthropy: a strategic approach to the bottom-line. California Management Review 1987;29:49-61.

3 Kotler P. Marketing management: analysis, planning, implementation, and control, 9 th ed. Upper Saddle River, New Jersey: Prentice Hall, 1997

4 Ukman L. The special event: finding its niche. Public Relations fournal 1987;40:21

5 Saxton E. Sponsorship and marketing-11. National Dragster, 3 February 1995. http://northernthunder.com/ saxton 1. html, downloaded 8 November 2000.

6 IEG, Inc. IEG's complete guide to sponsorship: everything you need to know about sports, arts, event, entertainment and cause need to know about sports, arts, event, enter
marketing. Chicago: IEG, Inc, 1999.

7 Federal Trade Commission. Federal Trade Commission report to Congress for the year 1996: pursuant to the Federal Cigarette Advertising and Labeling Act. Washington, DC: Federal Trade Commission, 1998.

8 Federal Trade Commission. Federal Trade Commission: cigarette report for 1999. Washington, DC: Federal Trade Commission, 2001

9 Blum A. Tobacco industry sponsorship of sports: a growing dependency. In: Durston B, Jamrozik K, eds. Tobacco and health 1990 - the global war: proceedings of the Seventh World Conference on Tobacco and Health. Perth, Australia: Health Department of Western Australia, 1990:882-4.

10 Buchanan DR, Lev J. Beer and fast cars: how brewers target blue-collar youth through motor sport sponsorships. San Rafael, 
California: Marin Institute for the Prevention of Alcohol and Other Drug Problems and AAA Foundation for Traffic Safety, 1990 .

11 Slade J. Tobacco product advertising during motor sports broadcasts: a quantitative assessment. Presented at the Ninth World Conference on Tobacco and Health, 10-14 October 1994

12 Madden PA, Grube JW. The frequency and nature of alcohol and tobacco advertising in televised sports, 1990 through 1992. Am f Public Health 1994;84:297-9.

13 Blum A. The Marlboro Grand Prix: circumvention of the television ban on tobacco advertising. N Engl F Med 1991; 324:913-7.

14 Connolly GN, Orleans CT, Blum A. Snuffing tobacco out of sport. Am F Public Health 1992;82:351-3.

15 US Department of Health and Human Services. Preventing tobacco use among young people. A report of the Surgeon General, 1994. Atlanta, Georgia: Public Health Service, Centers for Disease Control and Prevention, Office on Smoking and Health, 1994. (US Government Printing Office Publiand Health, 1994. (US Government

16 Davis RM. Current trends in cigarette advertising and marketing. New Engl f Med 1987;316:725-32.

17 Robinson RG, Pertschuk M, Sutton C. Smoking and African Americans: spotlighting the effects of smoking and tobacco promotion in the African American community. In: Samuels SE, Smith MD, eds. Improving the health of the poor: strategies for prevention. Menlo Park, California: The Henry J. Kaiser Family Foundation, 1992:123-81.

18 Robinson RG, Barry M, Bloch M, et al. Report of the Tobacco Policy Research Group on Marketing and promotions targeted at African Americans, Latinos, and Women. Tobacco Control 1992;1(suppl):S24-30.

19 Tuckson RV. Race, sex, economics, and tobacco advertising. 7 Natl Med Assoc 1989;81:1119-24.

20 US Department of Health and Human Services. Tobacco use among U.S. racial/ethnic minority groups: African Americans, American Indians and Alaska Natives, Asian Americans and Pacific Islanders, Hispanics. A report of the Surgeon General, 1998. Atlanta, Georgia: Centers for Disease Control and 1998. Atlanta, Georgia: Centers for Disease Control and
Prevention, Office on Smoking and Health, 1998. (US Government Printing Office Publication No S/N 017-001Government

21 Maxwell B, Jacobson M. Marketing disease to Hispanics: the selling of alcohol, tobacco, and junk foods. Washington, DC: Center for Science in the Public Interest, 1989.

22 Ernster VL. Women, smoking, cigarette advertising and cancer. Women and Health 1986;11:217-35.

23 White TC. Ethical considerations in accepting financial support from the tobacco industry. American Council on Science and Health Special Report. Washington, DC: American Council on Science and Health. 1991:1-11

24 IEG, Inc. IEG custom research report for Boston University School of Public Health. Chicago: IEG, Inc, 1998.

25 Siegel M. Tobacco industry sponsorship in the United States, 1995-1999. Boston: Boston University School of Public Health, 2000. URL: http://dcc2.bumc.bu.edu/tobacco.
26 Siegel M. Countering tobacco motor sports sponsorship as a promotional tool: Is the tobacco settlement enough? $\mathrm{Am}$ Public Health (in press).

27 Competitive Media Reporting. CMR trend report. New York: Competitive Media Reporting, 2000.

28 Anon. Brown \& Williamson contributes $\$ 3$ million to Papa John's Cardinal Stadium project (news release). Louisville, Kentucky: Brown \& Williamson Tobacco. 10 October 1996. Access date: 25 October 2000. URL: http:// www.brownandwilliamson.com $/ 3$ library $/ 5$ archive/ stadium.html

29 Anon. The Blues Foundation selects 17 recipients for the "Keeping the Blues Alive" award (press release). Memphis, Tennessee: The Blues Foundation. 10 May 1999. Accessed 27 October 2000. URL: http:// www.handyawards.com/1999/news/051199.html

301999 Hispanic Corporate 100: The one hundred companies providing the most opportunities for Hispanics. Hispanic Magazine (Hispanic Online). January-February 1999. URL: http://www.hisp.com/janfeb99/PHILIP.html, accessed 30 October 2000

31 Federal Trade Commission. Federal Trade Commission report to Congress for the years 1998 and 1999: pursuant to the Comprehensive Smokeless Tobacco Health Education Act of 1986. Washington, DC: Federal Trade Commission, 2001.

32 Federal Trade Commission. Federal Trade Commission report to Congress for the year 1998: pursuant to the Federal Cigarette Advertising and Labeling Act. Washington, DC: Federal Trade Commission, 2000.

33 Bragg R. Tobacco industry has changed its ways, executive says. New York Times. 13 June 2000:A24.

34 Tobacco Institute. Responsible living for teenagers: a public service proposal for the tobacco industry. Lorillard Tobacco Company. May 1982. Accessed 1 November 2000. Bates No 04210397-0441. URL: http://www.lorillarddocs.com/ PDF/04210397_0441

35 Keedle J. The tobacco industry's special interests - art world in bed with Philip Morris. Accessed 8 February 1999. URL: http://www.democracyworks.org/archive/dmarchives/nov/ culture.tobac1.html

36 Jackson DZ. Philip Morris offers its solutions to tough environmental problems. The Boston Globe. 2 July 1997:A18.

37 National Association of Attorneys General. Multistate settlement with the tobacco industry. Boston, Massachusetts: Tobacco Control Resource Center, Inc. and the Tobacco Products Liability Project, 2000. Accessed 7 November 2000. URL: http://tobacco.neu.edu/Extra/ multistate_settlement.htm\#MASTER

38 Holman CDJ, Donovan RJ, Corti B, et al. Banning tobacco sponsorship: replacing tobacco with health messages and creating health-promoting environments. Tobacco Control 1997;6:115-21.

39 Powles JW, Gifford S. Health of nations: lessons from Victoria, Australia. BMF 1993;306:125-7.

40 Musk AW, Shean R, Walker N, et al. Progress on smoking control in Western Australia. BMf 1994;308:395-8.

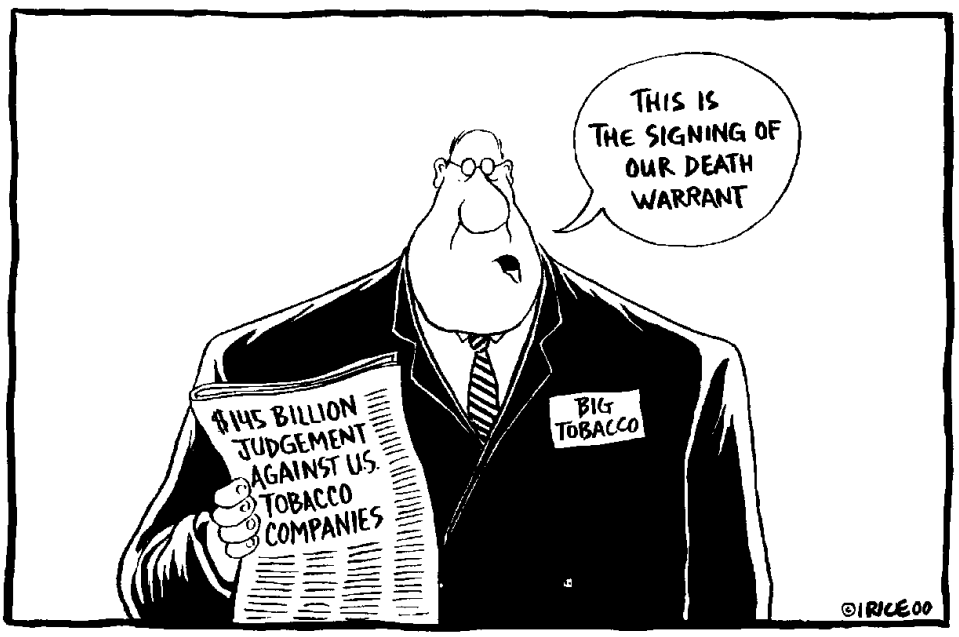

A CASE OF THE LUNG CALLING THE kETTLE BLACK:

(C) Ingrid Rice. 